\title{
Identification of Regional Climatic Conditions Favorable for Development of European Canker of Apple
}

\author{
Robert M. Beresford and Kwang Soo Kim
}

\author{
The New Zealand Institute for Plant \& Food Research Ltd., Plant \& Food Research Mount Albert, Private Bag 92 169, Auckland Mail \\ Centre, Auckland 1142, New Zealand. \\ Current address of K. S. Kim: Department of Plant Sciences, Seoul National University, Seoul, 151-921, Korea. \\ Accepted for publication 20 August 2010.
}

\begin{abstract}
Beresford, R. M., and Kim, K. S. 2011. Identification of regional climatic conditions favorable for development of European canker of apple. Phytopathology 101:135-146.

Months of the year with high risk of European canker (Neonectria galligena) development in areas of the United States, Chile, England, and Northern Ireland were determined from published data. Moving-window analysis of long-term climatic data was used to classify disease risk in these areas in relation to rainfall and temperature conditions using the degree of agreement statistic. Greatest agreement occurred when it both rained on $>30 \%$ of days/month and there was an average of $>8 \mathrm{~h} /$ day with

tended to be areas where the thresholds were exceeded more often and by greater amounts. Areas at higher latitudes $\left(>52^{\circ}\right)$ with frequent summer rainfall appeared to be most prone to European canker, including the fruit rot phase of the disease, probably because summer temperatures were more favorable than at lower latitudes. The climatic thresholds derived for European canker could be useful for studies of disease establishment risk, surveillance, eradication, climate change impact assessment, and, possibly, for disease risk forecasting. The methods used in this study allowed conditions favorable for disease development to be identified even though quantitative regional disease data were lacking, and they could be useful for similar geoclimatic studies of other diseases.
\end{abstract} temperature of 11 to $16^{\circ} \mathrm{C}$. When these thresholds were applied in eight validation areas in New Zealand, Australia, the United States, The Netherlands, and Denmark, areas with reported higher risk of disease
Additional keywords: climatic analysis, regional climate.
European canker, caused by the fungus Neonectria galligena (Bres.) Rossman \& Samuels, is an important disease of apple in some temperate regions (16), where it can result in death of buds, shoots, spurs, and branches (14). In extreme cases, whole trees may have to be removed where a canker has girdled the main trunk. It can also cause eye rot of fruit, which is a serious problem in Northern Ireland (8) and is periodically problematic in England (2) and northwestern Europe (32) (e.g., The Netherlands [3]). The fungus produces conidia and ascospores, both of which are dispersed and cause infection during prolonged periods of rainy weather $(43,46)$. $N$. galligena enters the tree through natural or artificial wounds $(4,38,44,47)$. Leaf scars formed during leaf fall in autumn months are considered to be the major site of infection $(10,12,44)$.

$N$. galligena spreads within orchards by spores produced on infected wood $(27,43)$ and it can be introduced to new orchards with infected planting material from tree nurseries (27). Although spread via infected fruit has been cited as a possibility (9), there is no documented case of this actually occurring. It is most likely that $N$. galligena has been introduced to many apple-growing regions with planting material before international plant quarantine procedures existed. However, European canker does not occur in all regions where apple fruit are grown, and climate has an important influence on its geographic distribution $(9,16,42)$.

Climatic conditions favorable for European canker have been described as "mild, wet conditions" (27), and rainfall, surface wetness, and temperature have been cited as important deter-

Corresponding author: R. M. Beresford

E-mail address: Robert.beresford@plantandfood.co.nz

doi:10.1094/PHYTO-05-10-0137

(c) 2011 The American Phytopathological Society minants of disease risk $(12,13,24,39,43)$. Sporulation, spore dispersal, and infection of $N$. galligena are favored by rainfall (27); frequency or duration of rainfall is considered more important than amount of rainfall $(12,13,39)$. Although irrigation is necessary for apple production in drier climates, wetness provided by irrigation has not been cited as a factor influencing geographic distribution of the disease. Effects of temperature on in vitro spore germination (24) and on infection of leaf scars and pruning wounds in the field $(12,13,24,43)$ have been reported but the temperature conditions that constitute "mild" in relation to regional and seasonal variability in apple-growing regions have not been defined.

A wide range of temperatures have been reported to be suitable for $N$. galligena spore germination in vitro (e.g., 5 to $\left.32^{\circ} \mathrm{C}\right)(24)$ but field infection appears to occur over a narrower temperature range (13). Lattore et al. (24) reported that the optimum temperature for infection of leaf scars following inoculation was $15^{\circ} \mathrm{C}$, with no infection occurring at $<5^{\circ} \mathrm{C}$. Dubin and English (13) found that the number of hours per day at 11 to $16^{\circ} \mathrm{C}$ was significantly associated with both leaf scar infection and numbers of trapped ascospores, and that numbers of trapped ascospores were also significantly associated with number of hours per day at 5 to $10^{\circ} \mathrm{C}$.

Dubin and English (13) suggested that mean annual rainfall above a threshold of $1,000 \mathrm{~mm}$ was associated with European canker development in California, although this threshold would appear not to apply in all regions (e.g., in Kent, England, where European canker is a serious problem but mean annual rainfall is only 600 to $700 \mathrm{~mm}$ ) (27). Frequency or duration of rainfall has been reported to be more important than amount of rainfall $(13,43)$, and duration of surface wetness is important in European canker development $(12,24,38,47)$. Two weather-based risk models that use hourly surface wetness and temperature data have been 
proposed to provide disease risk warnings for European canker infection $(24,45)$.

This study sought to quantify associations between regional climate and regional occurrence of European canker and to derive climatic thresholds to predict areas where the disease could cause problems for apple production. The purpose was to provide a better understanding of the risk of disease establishment from the possible introduction of this pathogen to new areas $(40,41)$ and to help the planning of efficient pathogen surveillance, eradication, or disease control measures (15).

\section{MATERIALS AND METHODS}

Climatic variables. Using published literature (12,13,24, $38,39,44,45,47)$, temperature and rainfall variables were selected for analysis to determine threshold values that classified regions according to the risk that European canker would affect apple production. Variables chosen to represent temperature were number of hours per day in four different temperature ranges: 5 to 10 , 11 to 16,16 to 20 , and 20 to $25^{\circ} \mathrm{C}$. Because surface wetness is rarely available at standard weather stations, surface wetness duration was surrogated by rainfall frequency, as percentage of days with rain on an approximately monthly basis.

Study areas. Long-term climatic records were summarized in terms of the selected climatic variables in four reference areas in the United States, Chile, England, and Northern Ireland (Fig. 1), where monthly risk of European canker was determined from the literature (Table 1). In Sonoma County, as well as in other coastal counties in northern California, tree cankers can be problematic
$(12,13,31,43)$ and fruit infection, although reported (26), is uncommon. In southern Chile, rainfall and temperature conditions suitable for infection occur in some years $(24,25)$ but fruit infection does not appear to be problematic. In southern England, $N$. galligena causes serious and persistent problems with tree cankers $(27,44,46)$ and, additionally, in wet seasons, with fruit rots $(2,48)$. In Armagh, Northern Ireland, $N$. galligena causes both tree cankers and fruit rots $(8,27,38,39)$, which have a severe impact on apple production.

The climatic thresholds derived from the reference areas were subsequently examined in relation to long-term climatic data in eight independent validation areas, where spatial but not temporal occurrence of European canker has been reported (Table 1). These validation areas included areas in New Zealand (1), Australia (34), the United States (49), Denmark $(23,33)$, and The Netherlands (20) (Fig. 1). For these areas, published information was less detailed than for the reference areas but was sufficient to determine the degree to which European canker caused a disease problem.

For two validation areas, Wenatchee, WA and Geneva, NY (Table 1), the absence of reports about European canker was used to indicate that the disease was not a problem for apple production in these areas, even though the pathogen is known to occur $(18,32,49)$. Zeller (49) suggested that European canker would have no economic importance in areas near Wenatchee. In the eastern apple-growing areas of the United States, including Geneva, European canker has been considered to be a relatively minor disease (32). As further evidence of the pathogen's minimal impact in these regions, no management recommendations for

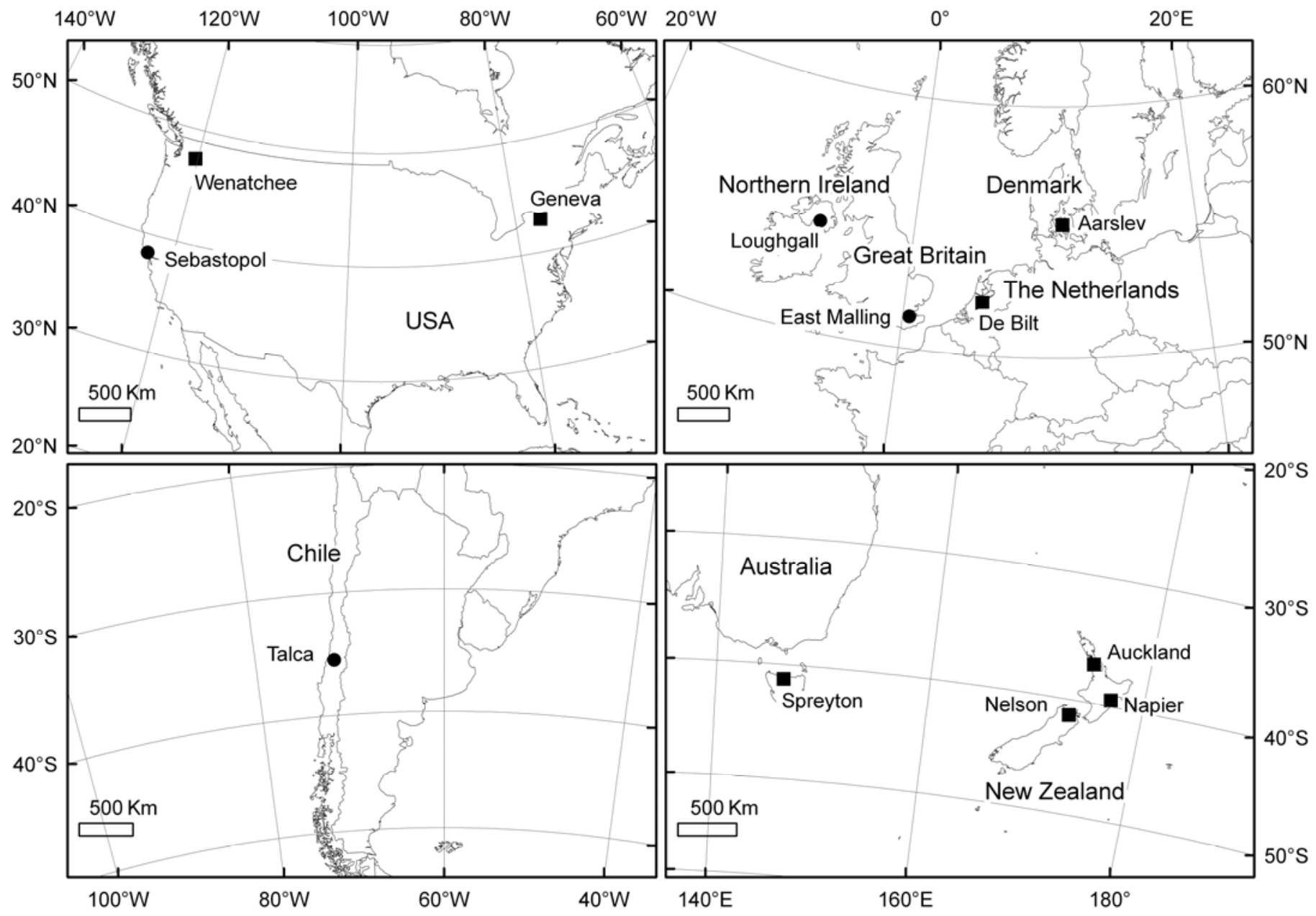

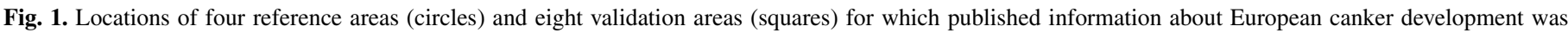
analyzed in relation to long-term climatic data. 
European canker are provided in these two areas according to local integrated pest management programs available from Washington State University (http://wsprs.wsu.edu) and Cornell University (http://www.nysipm.cornell.edu).

Climatic data. Daily weather data were obtained from the National Climate Data Center Global Surface Summary of the Day (GSOD) database, which contains data from $>9,000$ weather stations worldwide and which has been used for other ecological studies $(21,30)$. Daily rainfall and temperature data were extracted for weather stations close to the reference and validation areas (Table 1). The GSOD dataset contained rain- and snow-day indicators as well as amount of precipitation each day. It was assumed that rainfall occurred on days with precipitation $>0.254 \mathrm{~mm}$ and no indicated snowfall. Rainfall was also assumed to have occurred on days when the rain-day indicator showed occurrence of rainfall, even though the precipitation value was 0 or missing. To calculate hours in a specific temperature range, hourly temperature values were interpolated from daily maximum and minimum data using the "WAVE method" (Appendix).

For East Malling, Kent, England, the closest available GSOD site was the Gravesend-Broadness station, which was $23 \mathrm{~km}$ distant and was a drier site than East Malling itself, according to climate maps of the region available from the U.K. Meteorological Office (http://www.metoffice.gov.uk/climate/uk/averages/). Therefore, daily weather data were obtained directly from the horticultural research station at East Malling (Table 1). For Geneva, New York, daily precipitation and temperature data were obtained from a weather station linked with the National Weather Service's Cooperative Observer Program (http://cdo.ncdc.noaa.gov/ dly/DLY).

The sites Talca, Loughgall, and Aarslev had no nearby weather station within $20 \mathrm{~km}$ (Table 1). To determine whether the closest GSOD stations would represent climatic conditions at the sites of interest for the disease risk analyses, climate data at these sites were compared with high spatial resolution (e.g., 5 arc min) global climate surfaces from the WorldClim dataset (17). Monthly precipitation data were extracted from the surface locations of each study area and were compared with the monthly data at the corresponding GSOD stations. Slopes of the linear regression lines were $0.88,0.92$, and 1.01 for Talca, Loughgall, and Aarslev, respectively. The $R^{2}$ values for these sites were 0.96 to 1.00 . For the comparison between Talca and Curico, the most distant site $(63 \mathrm{~km}), 97 \%$ of variation in monthly precipitation at Talca was explained using monthly data at Curico. This was considered adequate for the purpose of this study.

Determination of climatic thresholds using moving-window analysis. Associations between European canker risk in the reference areas and the number of hours within the selected temperature ranges and the rainfall frequency were examined using averages of long-term climatic data. Averaging was done using moving-window analysis to provide continuity between consecutive averages for a specified time period (e.g., month) so that a clear climatic signal was available to derive statistical relationships between climate and disease risk. Moving-window analysis uses a time window of defined duration that is moved or slid along the total timeframe of interest, with successive window start times shifted by a small increment (22). For this study, a 4-week (28-day) window was used, over a total timeframe $>10$ years for each reference area, with an increment between successive windows of 1 week. In each year, there were 52 4-week windows, and climatic variables within each window were averaged over all the years in the data set.

Because a year does not contain exactly 52 weeks, the arrangement of windows was adjusted in each year to ensure the same window approximated the same month through the whole dataset. The week (Sunday to Saturday) that contained 1 January was used to define the first window of each year, then each successive window was advanced 1 week. The extra days in December, after the end of the 52nd window, were assigned to the windows that contained 1 January in the next year (Fig. 2A). Actual days of the year in each window differed by year but the variation was relatively small ( $<7$ days). This method was easy to apply because the week of the year that contained each day could be determined from a given date for any year using a statistical analysis program (JMP; SAS Institute, Inc., Cary, NC).

European canker risk was categorized as either high or low by area and by month from published information $(13,24,39,43,44)$. In Sonoma County, CA, Dubin and English (13) reported that November was an important month for European canker development. Wilson (43) suggested that infection could occur during the period from December to February if rainfall occurred frequently. In southern Chile, leaf scar infection causes damage under certain weather conditions during leaf fall (25), and a weather-based risk model identified that conditions suitable for infection occurred more frequently in May than in other months (24). In southern England, Wiltshire (44) reported that leaf fall in early autumn (September to October) was the period when infection was

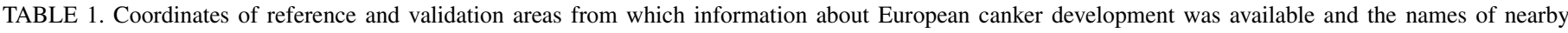
weather stations from which data were extracted from the Global Summary of the day (GSOD) database ${ }^{a}$

\begin{tabular}{|c|c|c|c|c|}
\hline Study area & Coordinate & Date range & Station name & $\mathrm{D}(\mathrm{km})^{\mathrm{b}}$ \\
\hline \multicolumn{5}{|l|}{ Reference areas } \\
\hline \multirow[t]{2}{*}{ Sebastopol, Sonoma, CA, United States (13) } & $38^{\circ} 24^{\prime} \mathrm{N} 122^{\circ} 19^{\prime} \mathrm{W}$ & 1973-1999 & Santa Rosa (AWOS) & 13 \\
\hline & $\ldots$ & $2000-2007$ & Santa Rosa (AWOS) & 13 \\
\hline Talca, Maule, Chile (25) & $35^{\circ} 25^{\prime} \mathrm{S} 71^{\circ} 39^{\prime} \mathrm{W}$ & $1973-2007$ & Curico & 63 \\
\hline East Malling, Kent, England (27) & $51^{\circ} 16^{\prime} \mathrm{N}^{\circ} 26^{\prime} \mathrm{E}$ & 1990-2008 & East Malling Research & 1 \\
\hline Loughgall, Armagh, Northern Ireland (27) & $54^{\circ} 24^{\prime} \mathrm{N} 6^{\circ} 36^{\prime} \mathrm{W}$ & 1985-2007 & Glenanne & 21 \\
\hline \multicolumn{5}{|l|}{ Validation areas } \\
\hline Auckland, New Zealand (1) & $36^{\circ} 50^{\prime} \mathrm{S} 174^{\circ} 45^{\prime} \mathrm{E}$ & $1973-2007$ & Auckland Airport & 20 \\
\hline \multirow[t]{2}{*}{ Napier, Hawke's Bay, New Zealand (1) } & $39^{\circ} 29^{\prime} \mathrm{S} 176^{\circ} 54^{\prime} \mathrm{E}$ & $1973-1988$ & Napier Airport & 7 \\
\hline & $\ldots$ & 1992-2007 & Napier Aerodrome AW & 5 \\
\hline \multirow[t]{2}{*}{ Nelson, Tasman, New Zealand } & $41^{\circ} 16^{\prime} \mathrm{S} 173^{\circ} 17^{\prime} \mathrm{E}$ & $1973-1991$ & Nelson Aerodrome & 6 \\
\hline & $\ldots$ & $1992-2007$ & Nelson Aerodrome AW & 5 \\
\hline Spreyton, Devon, Tasmania, Australia (34) & $41^{\circ} 13^{\prime} \mathrm{S} 146^{\circ} 20^{\prime} \mathrm{E}$ & $1997-2007$ & Sheffield School FA & 17 \\
\hline \multirow[t]{2}{*}{ Wenatchee, Chelan, WA, United States (49) } & $47^{\circ} 25^{\prime} \mathrm{N} 120^{\circ} 19^{\prime} \mathrm{W}$ & 1973-1999 & Wenatchee/Pangborn & 10 \\
\hline & $\ldots$ & $2000-2007$ & Wenatchee/Pangborn & 10 \\
\hline Geneva, Ontario, NY, United States & $42^{\circ} 53^{\prime} \mathrm{N} 77^{\circ} 02^{\prime} \mathrm{W}$ & $1973-2008$ & Geneva Rsch Farm & 0 \\
\hline Aarslev, Denmark $(23,33)$ & $55^{\circ} 18^{\prime} \mathrm{N} 10^{\circ} 26^{\prime} \mathrm{E}$ & $1973-2007$ & Odense/Beldringe & 21 \\
\hline De Bilt, Utrecht, The Netherlands $(3,20)$ & $52^{\circ} 03^{\prime} \mathrm{N} 5^{\circ} 08^{\prime} \mathrm{E}$ & $1973-2007$ & De Bilt & 5 \\
\hline
\end{tabular}

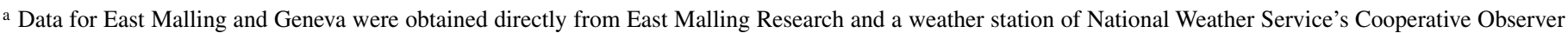
Program, respectively.

b Indicates distance between locality and nearby weather station. 
prevalent and also that infection increased rapidly during spring, from April to May. Swinburne (39) reported that, in Northern Ireland, most infection occurred between spring and autumn (April to October).

To examine associations between the climatic variables averaged using the moving-window technique and European canker risk, monthly risk had to be assigned to windows. To identify the calendar month associated with each window, the 52 overlapping windows in a year were divided into 13 groups of 4, each with a start time designated A to D (Fig. 2B). Each group was assigned to a calendar month according to the numerical day of the year (starting 1 January) that occurred most frequently in the group. The frequency that each day of the year occurred within each group was determined empirically for the total timeframe of all reference areas pooled (Fig. 3). For example, day number 120 occurred with a frequency of 0.026 in group 5 and a frequency of 0.01 in group 6 . The risk for the group (windows A to D) was the risk for the month (Table 2) containing the day of the year that occurred most frequently in that group (Fig. 3, peaks).

Monthly disease risk was assigned to all windows in a group. For example, the 56th day of year was most frequent in group 3 (Fig. 3). At Sebastopol, the risk in February, where the peak of group 3 occurred, was "high" (Table 2). Thus, high risk was assigned to the four windows contained in group 3. At Talca in southern Chile, May was the only month to which high risk of European canker was assigned. The group associated with May represented climatic conditions between May and June whereas it was likely that the risk of European canker would be increasing
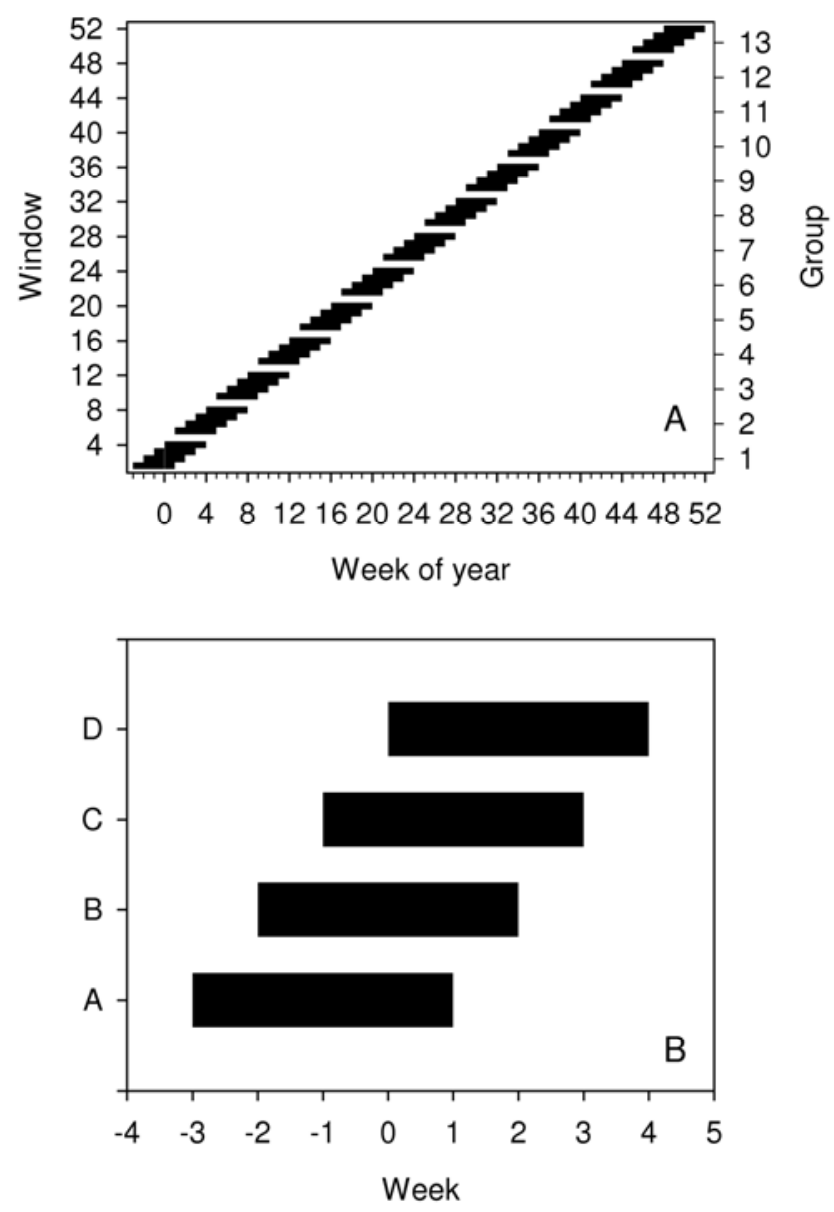

Fig. 2. A, Arrangement of moving windows within an example year showing 52 4-week moving windows in 13 groups. Days at the end of December from the previous year were assigned to windows that contained 1 January in the next year. B, Start date of each successive 4-week window was advanced by 1 week, creating four sets of windows with start times designated A to D. from mid-April, which is early autumn in southern Chile (22). To account for climatic conditions from mid-April to May in Talca, an additional group associated with April was also assigned high risk.

The degree of agreement between predicted climatic disease risk and the occurrence of canker was examined for various threshold values for the rainfall frequency and temperature variables. This allowed optimum thresholds for predicting European canker risk to be derived. It was assumed that climatic conditions were favorable for disease development when both thresholds were exceeded during a 4-week window. The mean percentage of rain days and the mean number of hours in each temperature range were calculated for each window, rather than group. When weather data were missing for $\geq 7$ days in the 4 -week window, the corresponding window was excluded from the analysis.

A four-cell contingency table was used to calculate the degree of agreement statistic $k$ between the risk level of windows and climatic conditions as follows:

\begin{tabular}{lll}
\hline & High risk & Low risk \\
\hline Favorable climate & Hits $(H)$ & Misses $(M)$ \\
Unfavorable climate & False alarms $(F)$ & Correct negatives $(N)$ \\
\hline
\end{tabular}

$H$ and $F$ denote the number of positive classifications that correspond to periods reported to have high and low risk in each window, respectively. $M$ and $N$ represent the number of negative classifications that were accompanied by windows of high and low risk, respectively. The $k$ statistic was given by (11):

$$
k=\frac{\Theta_{1}-\Theta_{2}}{1-\Theta_{2}}
$$

where $\Theta_{1}$ and $\Theta_{2}$ are the fraction of correct estimates and an estimate of the probability that the two conditions (e.g., climatic conditions and risk level) agree by chance, given the observed counts in the contingency table. The terms $\Theta_{1}$ and $\Theta_{2}$ are defined as follows:

$$
\Theta_{1}=\frac{H+N}{H+M+F+N}
$$

and

$$
\Theta_{2}=\frac{(H+M) \cdot(H+F)}{(H+M+F+N)^{2}}+\frac{(F+N) \cdot(M+N)}{(H+M+F+N)^{2}}
$$

A brute force search was used to find a pair of the threshold values that maximized the $k$ statistic between climatic suitability and risk level of European canker development. The $k$ values were calculated using all combinations of threshold values at the resolution of $1 \%$ and $0.1 \mathrm{~h}$ for rainfall frequency and temperature range variables, respectively. Because the numbers of rainfall and temperature thresholds were 100 and 240, respectively, there were 24,000 possible threshold pairs for rainfall and temperature variables for each temperature range. Values of $k$ were calculated using a total of 208 points derived from four reference areas and 52 windows, which were divided in the two-by-two table for each pair of the rainfall frequency and temperature thresholds. The maximum value of $k$ among these thresholds was used to identify the optimum thresholds.

McNemar's test, which is a nonparametric method for categorical data, was performed to examine the null hypothesis of marginal homogeneity (28). The null hypothesis was that the risk of European canker in a given window was not different between published observations and climatic conditions identified using the climatic thresholds. The McNemar test statistic, $Z$, was calculated as

$$
Z=\frac{(M-F)^{2}}{(M+F)}
$$


The value of $Z$ was considered to be a $\chi^{2}$ statistic with one degree of freedom.

Monthly climatic analysis. Monthly analysis was also performed for the reference areas, using the thresholds derived from the moving-window analysis, to determine whether averaging by month gave an interpretation of temporal trends in climatic favorability for European canker development similar to the moving-window analysis. When data were missing from a weather data set for $>1$ week in a month, the month was removed from the analysis. In the validation areas, monthly analysis, using the thresholds from the moving-window analysis in the reference areas, was used to evaluate the applicability of the climatic thresholds in a wider independent set of geographic areas. The suitability of climate was compared with the general degree to which European canker was or was not reported to be a problem in each validation area.

Probability of favorable climatic conditions and reported disease in validation areas. For the validation areas, published literature $(1,3,20,23,33,34,49)$ was interpreted to estimate the relative regional risk of $N$. galligena development in any given year as high or low, separately for tree canker and fruit rot risk (Table 3). These estimates were compared with the long-term frequency of years in which climatic conditions exceeded both the rainfall and temperature variable thresholds for seasonal intervals of either 12 months or for 3 months during summer (e.g., June, July, and August for the Northern Hemisphere). The number of events when the rainfall or temperature threshold was exceeded in a given month was counted for periods of at least 10 years.

The event where the temperature variable threshold was exceeded for a seasonal interval was designated $E_{T}$ and the event where the rainfall variable threshold was exceeded for a seasonal interval was designated $E_{R}$. It was assumed that $E_{T}$ and $E_{R}$ were independent for individual months. The probability of the event $P$ was calculated as the long-term frequency with which the threshold for the climatic variable was exceeded over a seasonal interval. For example, $P\left(E_{T}\right)$ for summer months was 0.5 when the temperature threshold was exceeded during these months in 15 years out of a 30-year period. Bayes' theorem was used to calculate the posterior probabilities of $E_{T}$ given $E_{R}$ and of $E_{R}$ given $E_{T}$. The posterior probability of $E_{A}$ given $E_{B}, P\left(E_{A} \mid E_{B}\right)$, was calculated as

$$
P\left(E_{A} \mid E_{B}\right)=\frac{P\left(E_{B} \mid E_{A}\right) \cdot P\left(E_{A}\right)}{P\left(E_{B} \mid E_{A}\right) \cdot P\left(E_{A}\right)+P\left(E_{B} \mid E_{A}^{-}\right) \cdot P\left(E_{A}^{-}\right)}
$$

where $P\left(E_{A}^{-}\right)=1-P\left(E_{A}\right)$ and $E_{A}$ and $E_{B}$ represent the events for variables $\mathrm{A}$ and $\mathrm{B}$, respectively. The values of $P\left(E_{T} \mid E_{R}\right)$ and $P\left(E_{R} \mid E_{T}\right)$ were calculated for each site for 12 months and for summer months to represent the risk of tree canker and fruit rot.

Variation in climatic risk in relation to season and latitude. Variation in the rainfall and temperature variables within an average year was analyzed by determining the coefficient of variation $(\mathrm{CV})$ of rainfall frequency $\left(C V_{\text {rain }}\right)$ and temperature range $\left(C V_{\text {temp }}\right)$ as follows:

$$
C V_{x}(\%)=\frac{\sigma_{x}}{\mu_{x}} \times 100
$$

where $\sigma$ and $\mu$ were standard deviation and average, respectively, of monthly summaries of each $x$ variable. Seasonal variation in the number of hours that air temperature was within the favorable range for European canker was examined in terms of latitude of reference and validation areas for those areas where the temperature threshold was exceeded in at least 1 month.

\section{RESULTS}

Climatic thresholds from moving-window analysis in reference areas. The $k$ statistic for degree of agreement between climatic variable threshold values and European canker risk, categorized by area and month (Table 2), had a maximum value of 0.71 at $>28 \%$ of days with rainfall and $>7.7 \mathrm{~h} /$ day at 11 to $16^{\circ} \mathrm{C}$ (Table 4). For this temperature range, values of $k>0.7$ were obtained for narrow ranges of both rainfall frequency $(\approx 30 \%)$, and hours in the temperature range $(\approx 8 \mathrm{~h} /$ day) (Fig. 4$)$. The proportion of correct estimates, $\Theta_{1}$, was 0.87 at these threshold values (Table 4). For the temperature range of 5 to $10^{\circ} \mathrm{C}$, the maximum values

TABLE 2. Assignment of months identified as having high risk of European canker development from published reports to groups comprising 4-week moving windows, which were used to determine climatic thresholds for disease risk in the reference areas Sebastopol, CA (United States), Talca, Maule (Chile), East Malling, Kent (England), and Loughgall, Armagh (Northern Ireland)

\begin{tabular}{llll}
\hline Site & High-risk months & References & High-risk groups \\
\hline Sebastopol & $1,2,11,12$ & 13,43 & $1,2,3,12,13$ \\
Talca & 5 & 24 & 5,6 \\
East Malling & $4,5,9,10$ & $38,39,44$ & $5,6,10,11$ \\
Loughgall & $4,5,6,7,8,9,10$ & 39 & $5,6,7,8,9,10,11$ \\
\hline
\end{tabular}

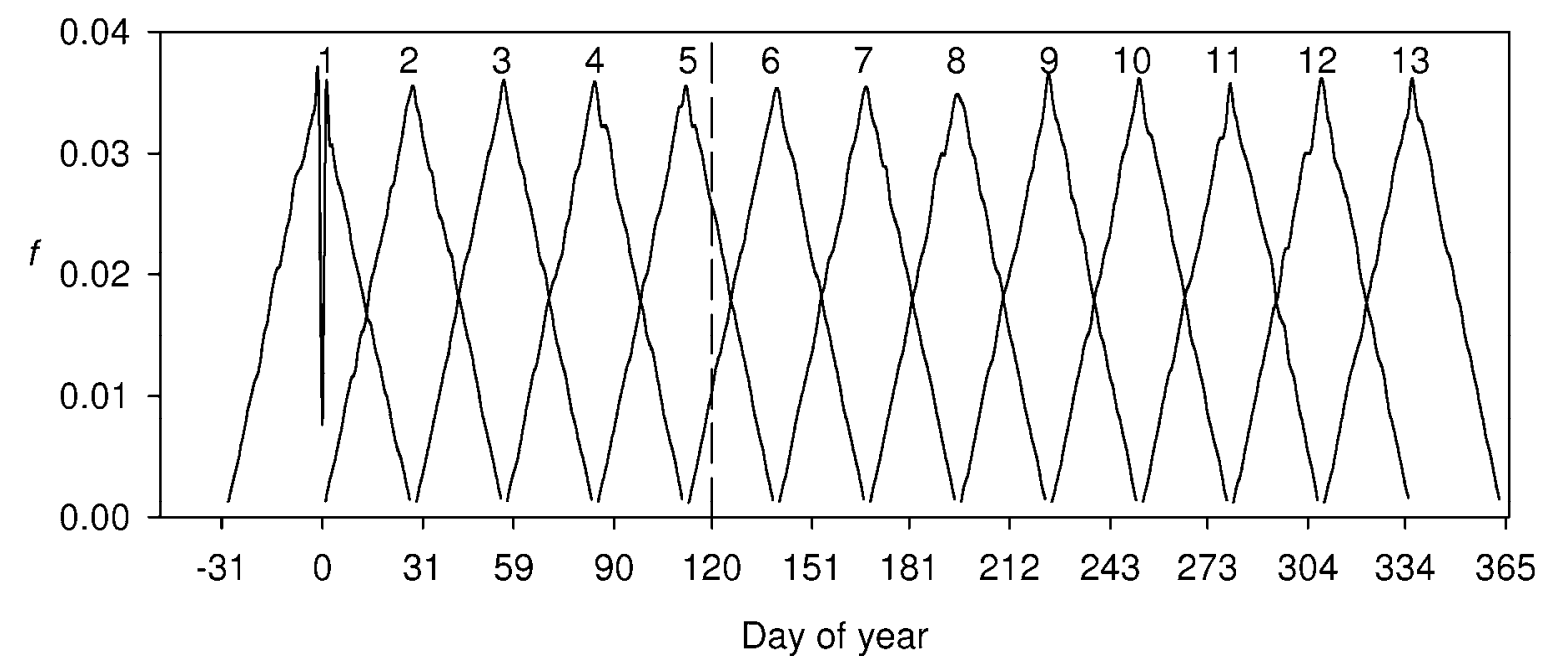

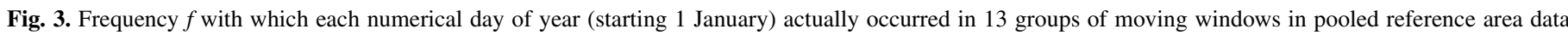

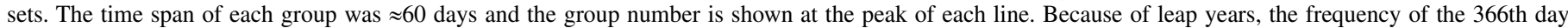

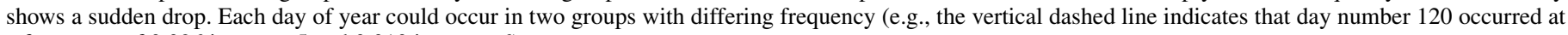
a frequency of 0.026 in group 5 and 0.010 in group 6). 
of $k$ and $\Theta_{1}$ decreased to 0.37 and 0.67 , respectively. Higher temperature ranges resulted in maximum $k$ values similar to those for 11 to $16^{\circ} \mathrm{C}$ : 0.69 and 0.67 for 16 to 20 and 20 to $25^{\circ} \mathrm{C}$, respectively. The corresponding threshold value for rainfall frequency was higher (40\% of days with rain), whereas that for the temperature variable was lower $(0.9$ and $0.1 \mathrm{~h}$ for 16 to 20 and 20 to $25^{\circ} \mathrm{C}$, respectively). McNemar's test indicated that a temperature range of 11 to $16^{\circ} \mathrm{C}$ was most suitable for assessment of climatic risk of European canker (Table 4), because the value of $Z$ was lower for that range than for other temperature ranges. Although the $\mathrm{Z}$ value was also relatively low (3.6) for hours at 16 to $20^{\circ} \mathrm{C}$, there was reasonable evidence $(P<0.1)$ for rejection of the null hypothesis that there was no difference between categorization of risk from published observations and climatic conditions identified using the 16 to $20^{\circ} \mathrm{C}$ temperature range.

Two-dimensional graphs of hours per day at 11 to $16^{\circ} \mathrm{C}$ and percentage of days with rainfall showed marked variation in seasonal pattern for these variables among the reference areas (Fig. 5). At Sebastopol and Talca, rainfall frequency varied greatly during the average year, being greater in windows corresponding to autumn and winter months and almost zero in those corresponding to summer months (Fig. 5A and B). At East Malling and Loughgall, the temperature variable varied more than the rainfall variable, and windows corresponding to summer months had many more days in the temperature range than those corresponding to winter months (Fig. 5C and D).

Monthly analysis of climatic variables in reference areas. Monthly averaging of rainfall frequency and hours in the 11 to $16^{\circ} \mathrm{C}$ temperature range (Fig. 6) showed annual patterns of European canker risk very similar to the moving-window analysis (Fig. 5). Ability to identify individual months made interpretation of seasonal risk easier by monthly analysis than by movingwindow analysis. For Sebastopol, the rainfall frequency and tem- perature conditions just exceeded the thresholds from November to March (late autumn to early spring) but not in other months (Fig. 6A). For Talca in Chile, the thresholds were exceeded only in May and June (late autumn and early winter), although the

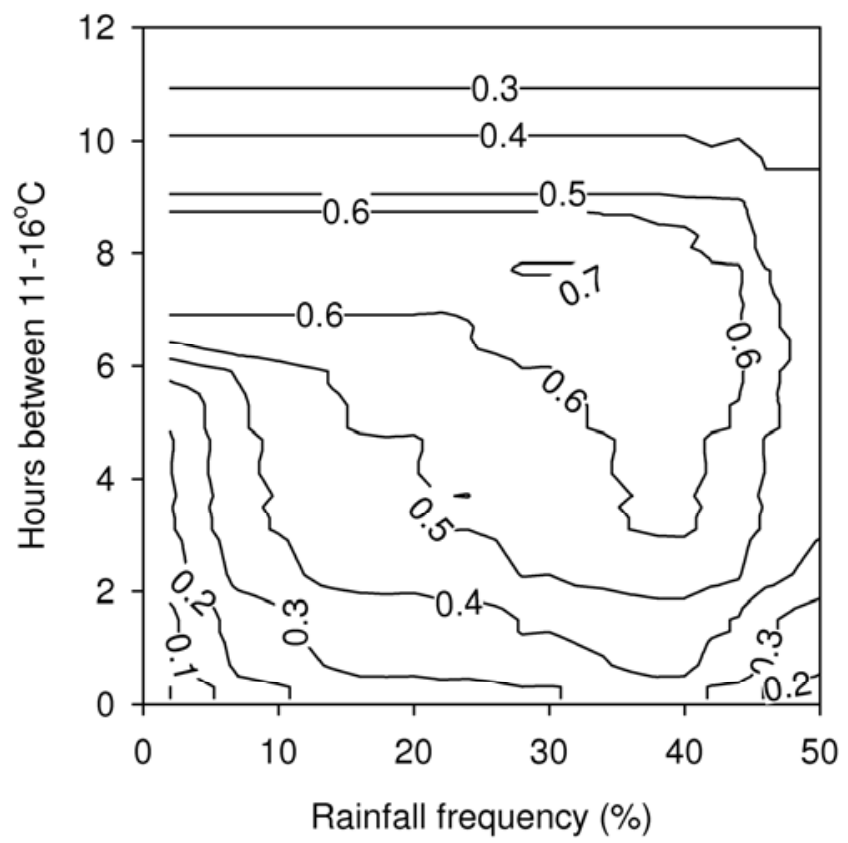

Fig. 4. Contours of the degree of agreement statistic, $k$, between European canker risk associated with each 4-week moving window and climatic favorability based on threshold values for rainfall frequency and number of hours per day with temperatures of 11 to $16^{\circ} \mathrm{C}$.

TABLE 3. Estimated regional annual risk interpreted from published data of tree canker and fruit rot infection caused by Neonectria galligena in relation to the posterior probability of climatic events in eight validation areas

\begin{tabular}{|c|c|c|c|c|c|c|}
\hline \multirow[b]{3}{*}{ Region } & & & \multicolumn{4}{|c|}{ Posterior probability } \\
\hline & \multicolumn{2}{|c|}{ Risk } & \multicolumn{2}{|c|}{ During 12 months } & \multicolumn{2}{|c|}{ During summer ${ }^{\mathrm{a}}$} \\
\hline & Tree canker $^{\mathrm{b}}$ & Fruit $\operatorname{rot}^{\mathrm{c}}$ & $P\left(E_{T} \mid E_{R}\right)^{\mathrm{d}}$ & $P\left(E_{R} \mid E_{T}\right)^{\mathrm{e}}$ & $P\left(E_{T} \mid E_{R}\right)$ & $P\left(E_{R} \mid E_{T}\right)$ \\
\hline Auckland & $\mathrm{H}$ & $\mathrm{L}$ & 0.97 & 0.65 & 1.00 & 0.40 \\
\hline Napier & $\mathrm{L}$ & $\mathrm{L}$ & 0.59 & 0.61 & 0.88 & 0.18 \\
\hline Nelson & $\mathrm{L}$ & $\mathrm{L}$ & 0.75 & 0.56 & 0.78 & 0.37 \\
\hline Spreyton & $\mathrm{L}$ & $\mathrm{L}$ & 0.59 & 0.47 & 0.50 & 0.82 \\
\hline Geneva & $\mathrm{L}$ & $\mathrm{L}$ & 0.93 & 0.11 & 1.00 & 0.06 \\
\hline Wenatchee & $\mathrm{L}$ & $\mathrm{L}$ & 0.50 & 0.05 & 0.00 & 0.00 \\
\hline De Bilt & $\mathrm{H}$ & $\mathrm{H}$ & 0.98 & 0.42 & 0.96 & 0.86 \\
\hline Aarslev & $\mathrm{H}$ & $\mathrm{H}$ & 1.00 & 0.40 & 1.00 & 0.73 \\
\hline
\end{tabular}

a June, July, and August for areas in the Northern Hemisphere and December, January, and February for areas in the Southern Hemisphere.

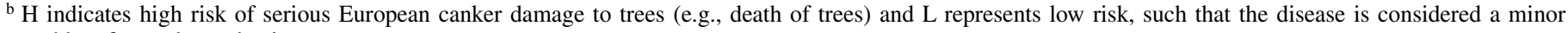
problem for apple production.

${ }^{\mathrm{c}} \mathrm{H}$ indicates high risk, such that fruit rot could occur unless controlled, and $\mathrm{L}$ represents low risk, such that the occurrence of fruit rot is rare.

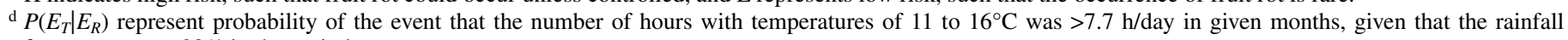
frequency was $>28 \%$ in the period.

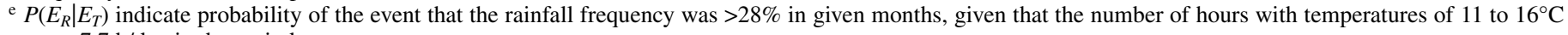
was $>7.7 \mathrm{~h} /$ day in the period.

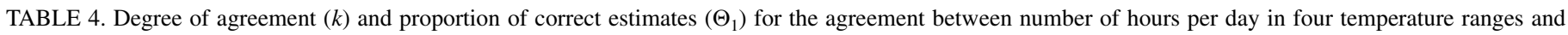
frequency of rainfall, and European canker risk that was categorized by region and month from published information.

\begin{tabular}{|c|c|c|c|c|c|c|}
\hline $\mathrm{T}_{\mathrm{R}}\left({ }^{\circ} \mathrm{C}\right)^{\mathrm{a}}$ & $\mathrm{T}_{\mathrm{D}}(\mathrm{h} / \mathrm{day})^{\mathrm{b}}$ & $\mathrm{R}_{\mathrm{F}}^{\mathrm{c}}$ & $k$ & $\Theta_{1}$ & $Z^{\mathrm{d}}$ & $P$ value ${ }^{\mathrm{d}}$ \\
\hline $5-10$ & 1.1 & 36 & 0.37 & 0.67 & 34.8 & 0.00 \\
\hline $11-16$ & 7.7 & 28 & 0.71 & 0.87 & 0.3 & 0.58 \\
\hline $16-20$ & 0.9 & 40 & 0.69 & 0.87 & 3.6 & 0.06 \\
\hline $20-25$ & 0.1 & 40 & 0.67 & 0.86 & 10.0 & 0.00 \\
\hline
\end{tabular}

a Temperature range.

${ }^{\mathrm{b}}$ Duration within the corresponding temperature range at the maximum $k$ value.

c Rainfall frequency threshold at the maximum $k$ value (\% of days).

d McNemar's test statistic and associated $P$ value to examine the null hypothesis of marginal homogeneity. 
rainfall threshold was also exceeded in July (Fig. 6B). At East Malling, Kent (Fig. 6C), the rainfall frequency threshold was exceeded in every month and the temperature range threshold was exceeded in September and October (autumn) and May and June (late spring and early summer). At Loughgall, Armagh the rainfall frequency threshold was exceeded in every month and the temperature range threshold was exceeded from May to October (late spring through summer to mid-autumn) (Fig. 6D).

European canker risk in validation areas. In New Zealand, severe tree cankers caused by $N$. galligena have been reported around Auckland, northern North Island (1) and the pathogen has been recorded around Nelson, northwest South Island (V. Herrera, personal communication), although the disease appears to be sporadic in that area. Around Napier in Hawke's Bay, the pathogen has been introduced on occasion but has not established (1). Monthly climatic analysis suggested that, in Auckland, rainfall conditions would be highly conducive to European canker development, with the rainfall frequency threshold exceeded in every month (Fig. 7A). The temperature range threshold was also exceeded in most months but not from December to March (summer to early autumn). In Nelson, the rainfall frequency and temperature thresholds were exceeded from April to May in autumn and from September to November in spring (Fig. 7B), supporting observations that conditions are less favorable for European canker in that area than in Auckland. In Napier, rainfall frequency and temperature conditions were close to the thresholds from April to November (mid-autumn to late spring), although the thresholds were only ever exceeded by a small amount (Fig. 7C). This is in agreement with observations that conditions in Napier are less favorable for European canker development than in Auckland or Nelson.

In Australia, European canker was reported to be present at Spreyton in northern Tasmania for a period of $\approx 40$ years, from almost 20 years prior to 1954, when an eradication program commenced, until it was last detected in 1974 (34). GSOD data near Spreyton showed that the rainfall frequency and temperature thresholds were just exceeded in April and May (autumn) and in October and November (spring) (Fig. 7D). It appeared that conditions around Spreyton were generally unfavorable for European canker development, which is consistent with the limited disease spread that was reported during the outbreak there (34).

At Wenatchee in central Washington State in the United States, there are no reports of European canker causing a disease problem, although the report by Zeller (49) of an isolated occurrence of $N$. galligena on fruit indicates that the pathogen is present there. At Wenatchee, the combined rainfall frequency and temperature range thresholds were not met in any month (Fig. 7E). This suggests that the climatic thresholds accurately reflected the low risk of European canker in that area. At Geneva in New York State in the northeast region in the United States, where European canker has been documented on other hosts but not on apple, there was no month during which the rainfall and temperature thresholds were met at the same time (Fig. 7F). However, rainfall frequency and temperature range variables were $48 \%$ and $7.6 \mathrm{~h}$ during September (early autumn), which was close to the threshold values.

In Denmark and The Netherlands, European canker causes serious damage to apple trees unless controlled $(20,23,33)$ and
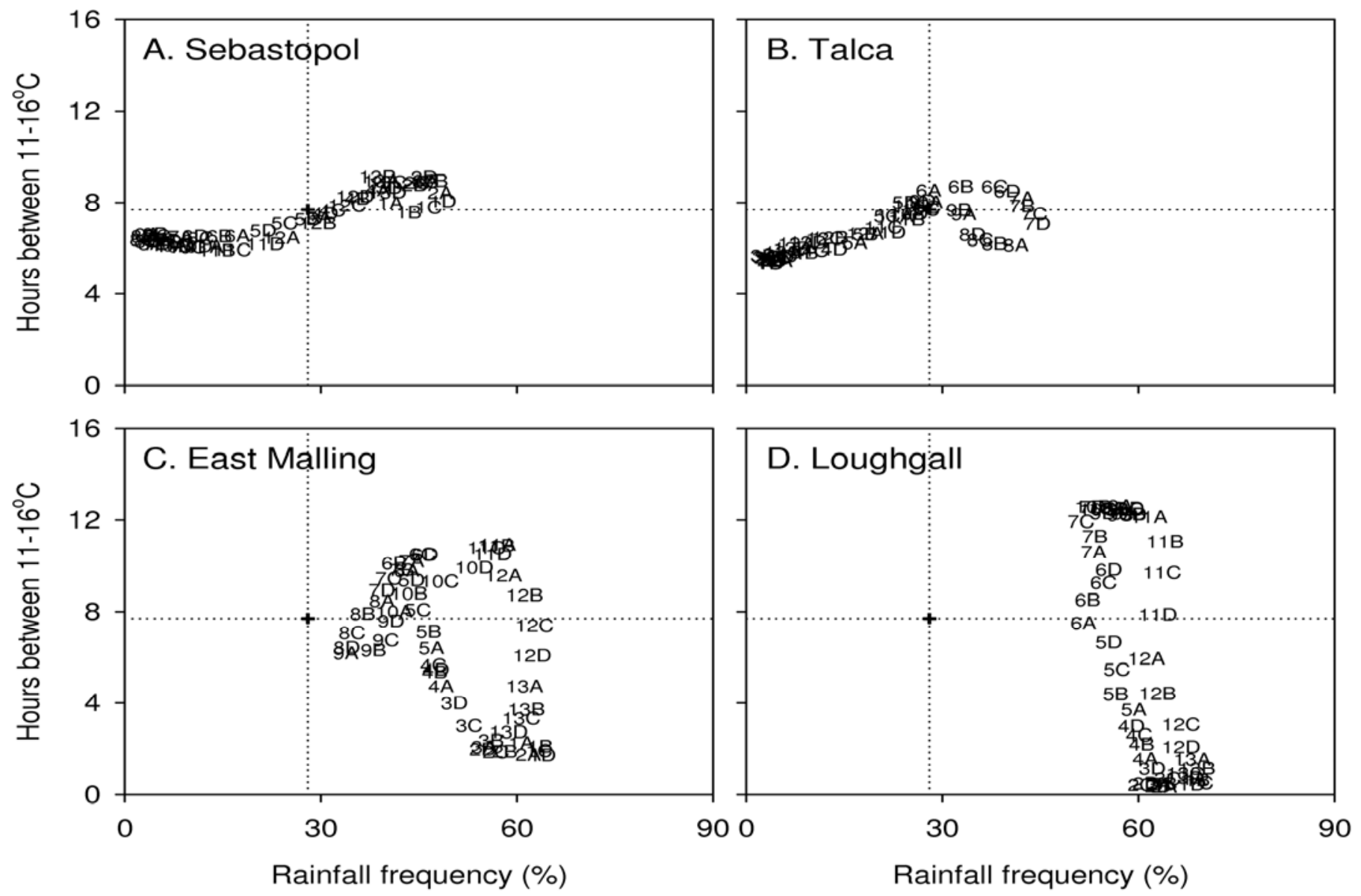

Fig. 5. Moving-window analysis of rainfall frequency and temperature range variables associated with European canker for A, Sebastopol, CA; B, Talca, Chile; C, East Malling, England; and D, Loughgall, Northern Ireland, showing mean frequency of days with rain and mean number of hours with temperatures of 11 to $16^{\circ} \mathrm{C}$ per day for each 4-week window. Alphanumeric labels represent the corresponding group of four overlapping windows, each with a different start date. Vertical and horizontal lines indicate climatic thresholds of $28 \%$ of days with rain and $7.7 \mathrm{~h} /$ day with temperatures of 11 to $16^{\circ} \mathrm{C}$, respectively. 
fruit rot can occur in these areas in severely cankered orchards $(3,20,32)$. GSOD data at Aarslev, Denmark and De Bilt, Utrecht, The Netherlands (Table 1) showed that the rainfall frequency threshold was exceeded in every month and that both thresholds were met or exceeded from May to October (late spring to mid-autumn) at both Aarslev (Fig. 7G) and De Bilt (Fig. 7H).

Probability of favorable climatic conditions and reported disease in validation areas. The high reported risk of tree cankers for the validation areas of Auckland, De Bilt, and Aarslev (Table 3$)$ was associated with high $(\geq 0.96)$ posterior probability of $E_{T}$ given $E_{R}, P\left(E_{T} \mid E_{R}\right)$, combined with moderate to high $(\geq 0.4)$ probability of $E_{R}$ given $E_{T}, P\left(E_{R} \mid E_{T}\right)$ (Table 3$)$. This pattern was true for probabilities calculated over either 12 months or 3 months during summer. Although, at Geneva, the values of $P\left(E_{T} \mid E_{R}\right)$ were also high (0.93 to 1.0$)$, they occurred with low values $(0.06$ to $0.11)$ of $P\left(E_{R} \mid E_{T}\right)$. The validation areas with high fruit rot risk classification (Aarslev and De Bilt) had high values $(\geq 0.96)$ of $P\left(E_{T} \mid E_{R}\right)$ over summer months, combined with high values $(\geq 0.73)$ of $P\left(E_{R} \mid E_{T}\right)$ (Table 3). Auckland, which was classified as low fruit rot risk, had high summer probability (1.0) of $E_{T}$ given $E_{R}$ but a lower (0.4) summer probability of $E_{R}$ given $E_{T}$. Therefore, the analysis of posterior climatic probabilities in the validation areas suggested that the climatic variable thresholds derived from moving-window analysis in the reference areas gave reasonable prediction of climatic risk of European canker using monthly analysis in the validation areas.

Variation in climatic risk in relation to season and latitude. For the reference and validation areas combined, monthly rainfall frequency and temperature range variables showed patterns of variation within an average year that differed according to region. Sebastopol and Talca (Fig. 6A and B) and, to a lesser extent, Spreyton (Fig. 7D) showed greater values for the CV for monthly rainfall frequency than for average daily hours at 11 to $16^{\circ} \mathrm{C}$ (Table 5). The climate in these areas was designated R-type, because variation in the rainfall variable was the dominant feature. For all the other areas, $\mathrm{CV}$ values for the temperature variable were greater than those for the rainfall variable. These areas were designated T-type climates. For the T-type climates at Loughgall (Fig. 6D), Aarslev (Fig. 7G), and De Bilt (Fig. 7H), the temperature range $\mathrm{CV}$ was more than six times that of the rainfall frequency CV (Table 5).

Suitability of temperature conditions for European canker development in different seasons varied with latitude across the reference and validation areas (Fig. 8). At lower latitudes (e.g., $<45^{\circ}$ ), more hours per day tended to be in the favorable 11 to $16^{\circ} \mathrm{C}$ range in winter than summer, because summer temperatures were often too high. At higher latitudes (e.g., $>52^{\circ}$ ), more hours per day tended to be favorable in summer than winter because winter temperatures were often too low. Trends with latitude were clearly seen among the three New Zealand sites (Fig. 7A to C). During summer (December to February), temperatures at the lowest-latitude site, Auckland $\left(37^{\circ} \mathrm{S}\right)$, were, on average, 11 to $16^{\circ} \mathrm{C}$ for only 2 to $5 \mathrm{~h} /$ day, whereas, at Napier $\left(39^{\circ} \mathrm{S}\right)$, it was 5 to $6 \mathrm{~h} /$ day and, in Nelson $\left(41^{\circ} \mathrm{S}\right)$, it was 6 to $8 \mathrm{~h} /$ day. The converse occurred in winter (June to August), when temperature was, on average, 11 to $16^{\circ} \mathrm{C}$ for $>12 \mathrm{~h} /$ day in Auckland, 7 to $9 \mathrm{~h} /$ day in Napier, and only 4 to $7 \mathrm{~h}$ /day in Nelson. Similar trends with latitude were also apparent in other areas in the study (e.g., East Malling and Loughgall) (Fig. 6C and D).
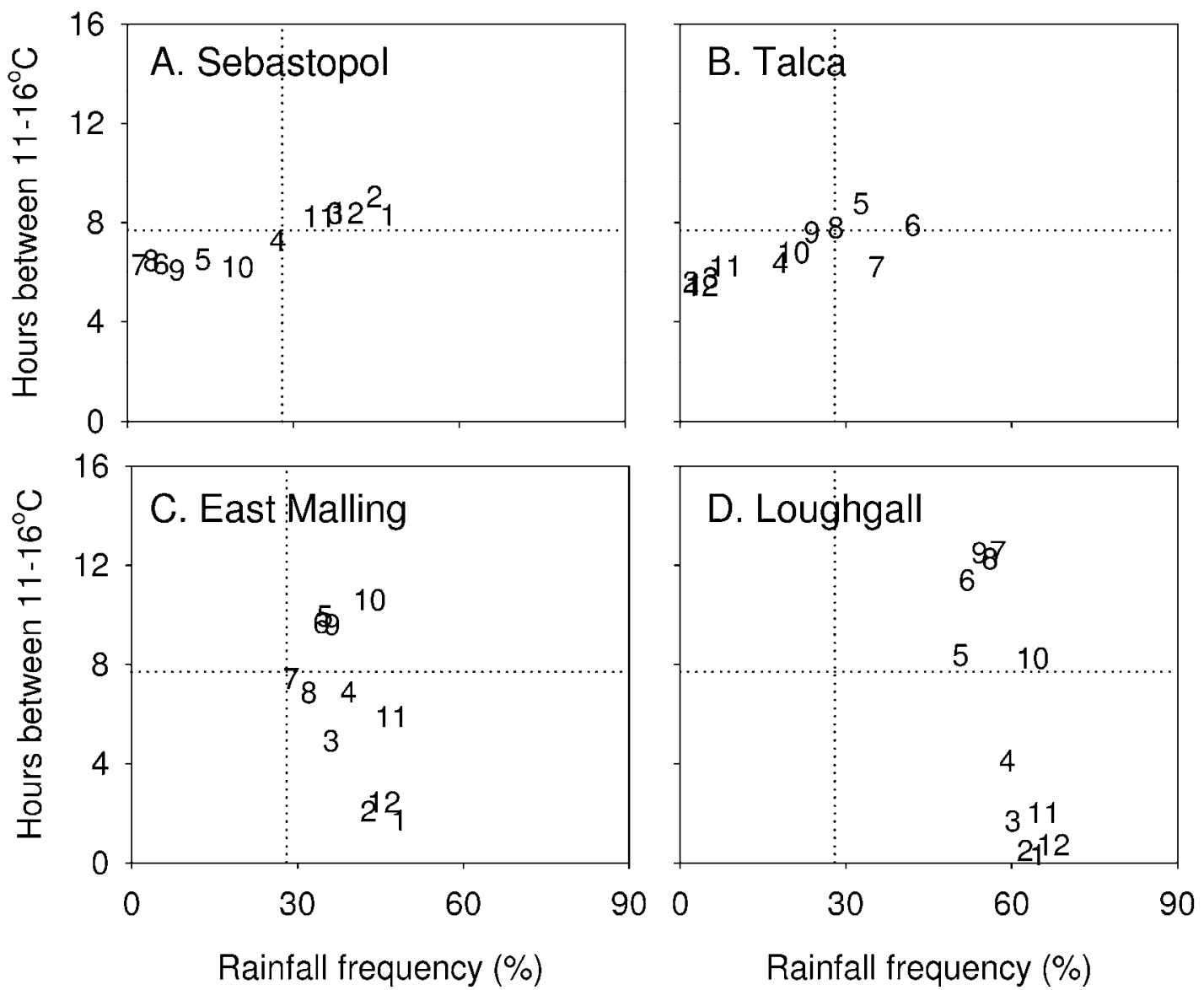

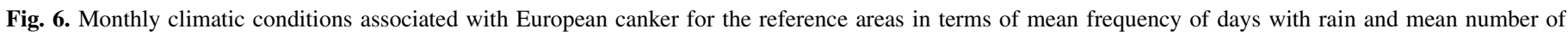
hours with temperatures of 11 to $16^{\circ} \mathrm{C}$ per day for A, Sebastopol, CA; B, Talca, Chile; C, East Malling, England; and D, Loughgall, Northern Ireland. The numeric label represents the month. Vertical and horizontal lines indicate climatic thresholds of $28 \%$ of days with rain and $7.7 \mathrm{~h} /$ day with temperatures of 11 to $16^{\circ} \mathrm{C}$, respectively. 


\section{DISCUSSION}

This study has shown that European canker is a problem in apple production regions where several months of the year have an average of $>30 \%$ of days with rainfall and temperature is 11 to $16^{\circ} \mathrm{C}$ for $>8 \mathrm{~h} /$ day. These thresholds differentiated areas where European canker is a severe problem (e.g., Northern Ireland and northwestern Europe) from those where it is seldom or never a disease problem (e.g., Wenatchee, WA and Geneva, NY). In several other areas, where the disease sometimes occurs but is not
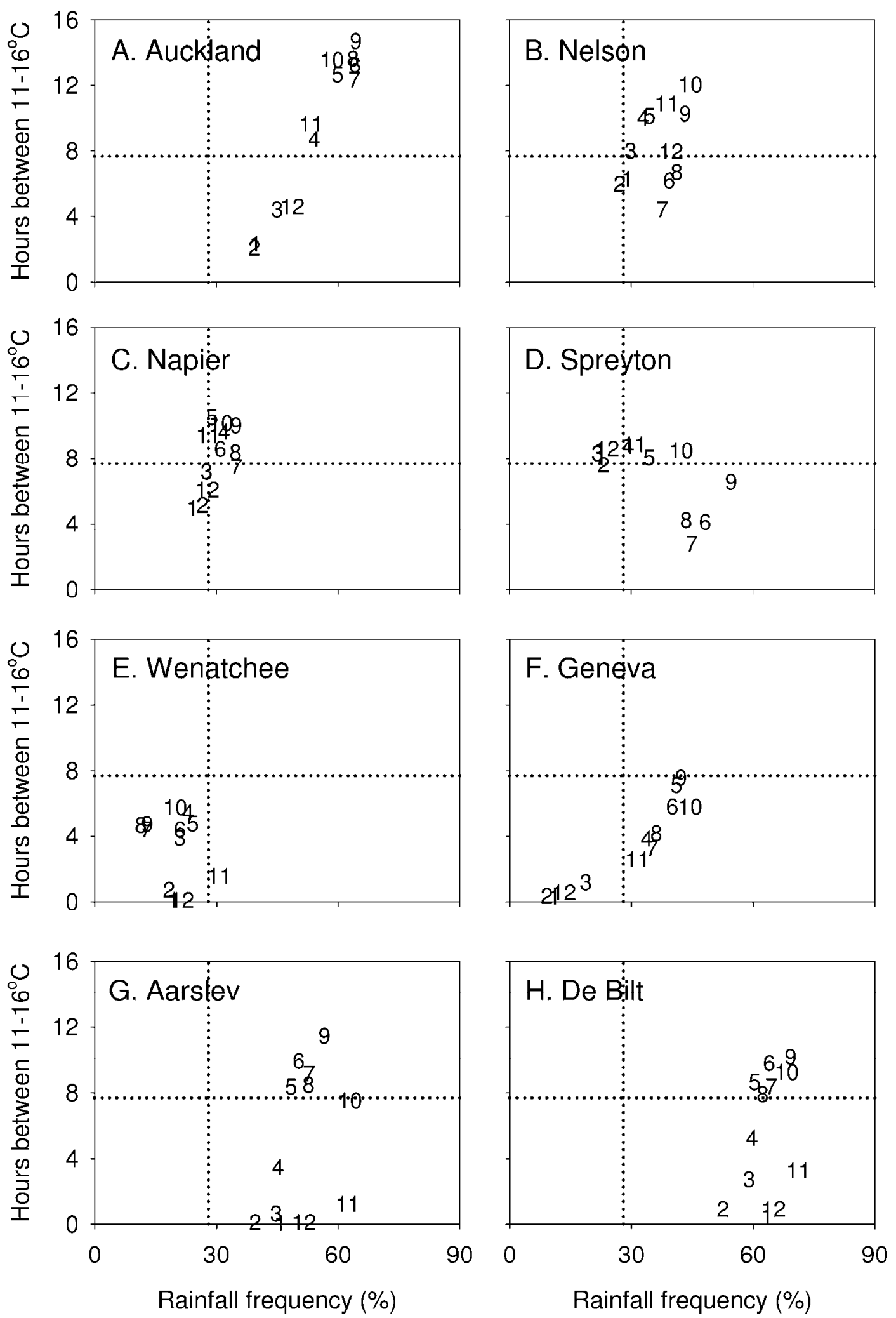

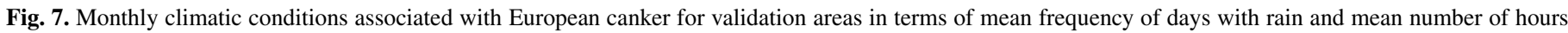
with temperatures of 11 to $16^{\circ} \mathrm{C}$ per day for A, Auckland, New Zealand; B, Nelson, New Zealand; C, Napier, New Zealand; D, Spreyton, Australia; E, Wenatchee, WA; F, Geneva, NY; G, Aarslev, Denmark; and H, De Bilt, The Netherlands. The numeric label represents the month. Vertical and horizontal lines indicate climatic thresholds of $28 \%$ of days with rain and $7.7 \mathrm{~h}$ /day with temperatures of 11 to $16^{\circ} \mathrm{C}$, respectively. 
a major problem (e.g., Sebastopol, Talca, and Napier), conditions are marginally favorable, with the climatic thresholds exceeded by a small amount in only a few months of the year. For favorable and marginally favorable areas, the months or seasons in which the thresholds were exceeded varied considerably. This was associated with regional differences in the seasonal pattern of change in the temperature and the rainfall variables. This seasonal variability confirms that a single annual climatic factor, such as annual rainfall $>1,000 \mathrm{~mm}(13)$, is unlikely to explain variation in European canker risk in all regions.

For areas with marginal to high risk of European canker, latitude influenced the pattern of variation in the temperature range variable within the average year and, hence, the pattern of predicted average risk. Low-latitude areas (e.g., $<45^{\circ}$ ) tended to have hot summer conditions, with a small number of days at 11$16^{\circ} \mathrm{C}$ and a correspondingly low summertime risk of European canker. In Sebastopol and Talca there was, additionally, low summer rainfall frequency, giving extremely low summertime risk. Low-latitude areas tended to have the most favorable temperature conditions during winter. In high-latitude areas (e.g.,

TABLE 5. Coefficients of variation $(\mathrm{CV} ; \%)$ of rainfall frequency and temperature range variables and climate type designations relating to favorability of climate for European canker development in four reference and eight validation areas

\begin{tabular}{lccc}
\hline Area & $\mathrm{CV}_{\text {rain }}(\%)^{\mathrm{a}}$ & $\mathrm{CV}_{\text {temp }}(\text { no. })^{\mathrm{b}}$ & Type $^{\mathrm{c}}$ \\
\hline Reference area & & & \\
$\quad$ Sebastopol, CA & 67.8 & 15.0 & $\mathrm{R}$ \\
Talca, Chile & 72.6 & 16.6 & $\mathrm{R}$ \\
East Malling, England & 15.8 & 48.9 & $\mathrm{~T}$ \\
$\quad$ Loughgall, Northern Ireland & 9.2 & 82.8 & $\mathrm{~T}$ \\
Validation area & & & \\
$\quad$ Auckland, New Zealand & 17.1 & 50.9 & $\mathrm{~T}$ \\
Napier, New Zealand & 11.5 & 23.9 & $\mathrm{~T}$ \\
Nelson, New Zealand & 15.5 & 28.9 & $\mathrm{~T}$ \\
Spreyton, Australia & 31.9 & 30.1 & $\mathrm{R}$ \\
Wenatchee, WA & 26.7 & 62.9 & $\mathrm{~T}$ \\
Geneva, NY & 42.7 & 74.2 & $\mathrm{~T}$ \\
Aarslev, Denmark & 13.6 & 88.9 & $\mathrm{~T}$ \\
De Bilt, The Netherlands & 7.9 & 67.1 & $\mathrm{~T}$ \\
\hline
\end{tabular}

${ }^{a}$ Mean percentage of days with rain per month.

${ }^{b}$ Average number of hours with temperatures of 11 to $16^{\circ} \mathrm{C}$ per day in a month.

${ }^{\mathrm{c}} \mathrm{R}$ indicates a climate characterized by $\mathrm{CV}$ for the rainfall frequency variable greater than $\mathrm{CV}$ for the temperature range variable and $\mathrm{T}$ indicates the converse. $>45^{\circ}$ ), temperatures were most favorable during summer and low winter temperatures appeared limiting to European canker development. This is confirmed by published data from Kent $\left(51^{\circ} \mathrm{N}\right)$, where increases in canker incidence in an apple planting occurred in spring and summer, coinciding with increasing temperature at that time (27).

The season in which apple trees are susceptible to $N$. galligena infection is important in European canker epidemiology $(38,44)$. This study considered susceptibility implicitly by analyzing separate months and considering which months were likely to have susceptible infection sites present. The importance of leaf scars as infection sites (44) suggests that regions where the climatic thresholds are exceeded during leaf fall might have higher risk. Data on months of apple leaf fall in each study area were not available but it was assumed that the main leaf fall months are October in the Northern Hemisphere and May in the Southern Hemisphere, with leaf fall occurring some weeks earlier at higher latitudes (e.g., $>50^{\circ}$ ) than at lower latitudes (e.g., $<40^{\circ}$ ). Apple cultivar also affects the time of leaf fall, and the interaction between cultivar and regional climate may partly determine the relative likelihood of different cultivars becoming infected within a region. Whereas, in the lowest-risk areas, Wenatchee and Geneva, the climatic thresholds were never exceeded in autumn, in all other areas, including the marginally favorable ones, both thresholds were exceeded in at least one autumn month. For higher-latitude areas, the temperature variable was above the threshold earlier in autumn (e.g., September to October at Loughgall, $54^{\circ} \mathrm{N}$ ) than in lower-latitude areas (e.g., November at Sebastopol, $38^{\circ} \mathrm{N}$ ), and this would presumably be coupled to earlier leaf fall in higher-latitude areas. The two-dimensional graphs indicated that areas in which the thresholds were exceeded by a greater amount in autumn were areas with greater European canker risk (e.g., East Malling).

In addition to autumn leaf scars, wounds associated with tree growth (e.g., growth cracks and basal leaf scars) can provide sites for infection during summer (38). The high-latitude areas with Ttype climates, where rainfall was never limiting and summer months had favorable temperatures (Loughgall, Aarslev, De Bilt, and East Malling), had greater reported risk of European canker development than the areas with R-type climates, characterized by hot, dry summer months (e.g., Sebastopol, Talca, and Spreyton). It appears that areas with summer conditions favorable for infection of growth-related wounds are at greater risk of European canker development. The areas with R-type climates and hot, dry summer conditions were areas where ascospores have been
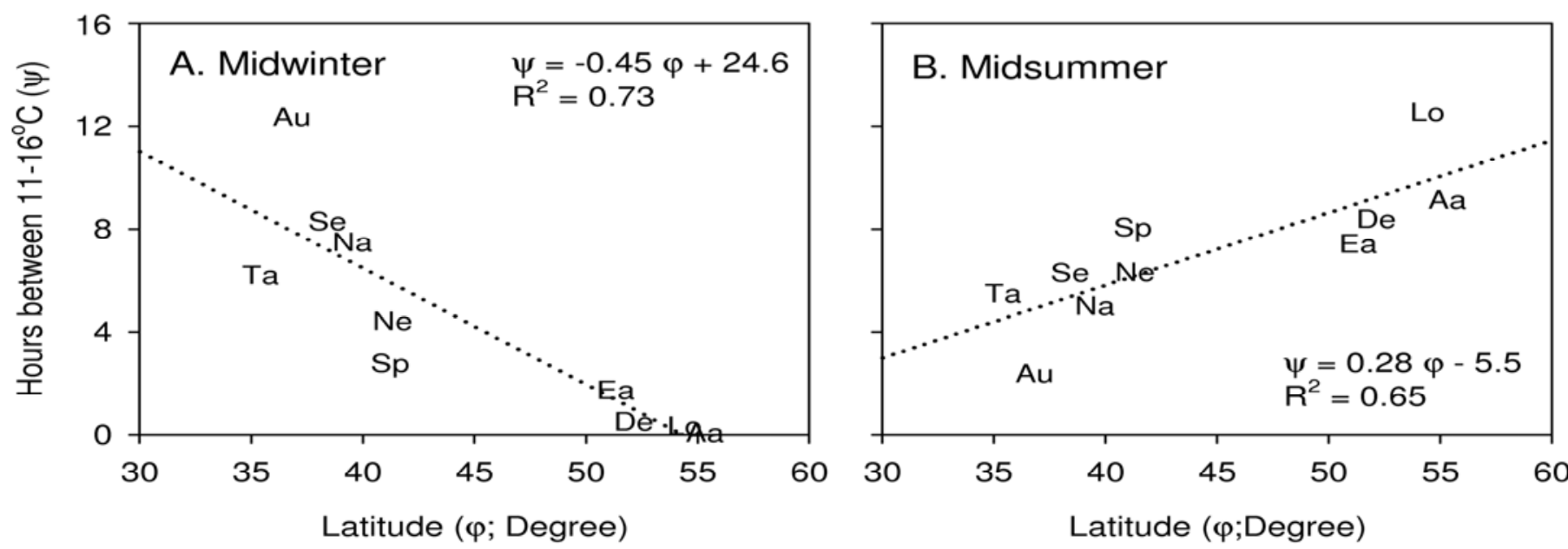

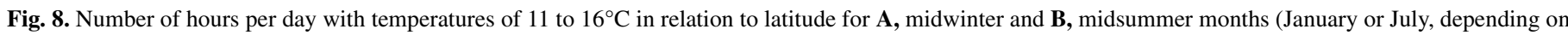

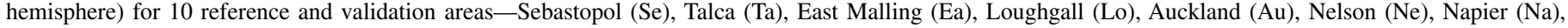

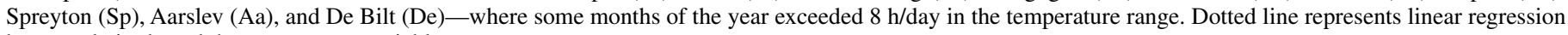
between latitude and the temperature variable. 
reported to be unimportant in the epidemiology of European canker, as in California $(13,24,43)$, and where perithecia have been reported not to produce mature ascospores, as in Tasmania (34).

Occurrence of $N$. galligena fruit rot predominates in higherlatitude areas (e.g., $>50^{\circ}$ ) in the United Kingdom and northwestern continental Europe $(2,8,20,23,27,38,39)$. In lower-latitude areas (e.g., $<45^{\circ}$ ), particularly those with low summer rainfall (e.g., Sebastopol and Talca), fruit rot does not appear to occur. Auckland, which is at a lower latitude $\left(37^{\circ} \mathrm{S}\right)$, has adequate rainfall but high summer temperatures. Although tree cankers are common, $N$. galligena fruit rot occurs rarely in Auckland (1). This is consistent with the suggestion that the fruit rot phase of European canker mainly occurs under the moderate summer temperatures that occur at higher latitudes.

European canker can occur in areas where the climate is classified as unfavorable using this climatic threshold approach (e.g., the report of European canker at Wenatchee, WA) even though the disease is not problematic in that area (49). In the case of Spreyton, Tasmania, which was predicted to have a climate that is at most marginally suitable for European canker, the disease was present there for $\approx 40$ years with very little spread (34). This suggests that these climatic thresholds could reliably predict the risk to apple production from the introduction of $N$. galligena to new areas.

Monthly climatic analysis and moving-window analysis gave the same general interpretation of geographic and temporal trends in European canker climatic risk. The moving-window analysis revealed greater detail in temporal trends within a year but was difficult to interpret because the time scale had 13 groups instead of 12 months. The moving-window analysis was necessary to provide sufficient data points to derive the climatic thresholds using the degree of agreement statistic (i.e., moving-window analysis provided 48 data points for each reference area, whereas monthly averages would provide only 12). The moving windows in this study were of set length, which differed from some other window-type analyses in plant pathology, including the WINDOW program (7) and window-pane analysis (22). In both of those studies, time windows of varying duration were used to identify climatic signals associated with disease over short or long time scales. In those studies, quantitative disease data were available. For example, Kriss et al. (22) examined associations between annual disease ratings of Fusarium head blight in wheat and weather conditions in various time windows. In this study, quantitative disease data were lacking and the moving-window analysis was instead used to detect repeating seasonal climatic signals over a relatively long time frame, which were then related to descriptive information about disease occurrence. This approach to finding relationships between disease and long-term climate could be useful in other studies where detailed disease information is not available.

The weather data used in this study may have had limitations because hourly temperatures had to be interpolated from daily data for most sites. However, previous studies suggest that estimates of hourly temperatures using daily data can be reasonably accurate $(5,35,36)$. A comparison of "WAVE method" estimates with actual hourly temperature analysis suggested that the WAVE method gave adequate estimates of temperature variables for the monthly analysis in this study (Appendix).

This study was carried out with little quantitative disease data, although relatively good availability of climatic data. This is a common problem for geoclimatic analyses of disease risk, where information about disease in relation to climatic conditions may be as subjective as the descriptors "mild" and "wet" that have been used for European canker (27). Use of the $k$ statistic in the reference areas in this study allowed published descriptive information on disease risk to be statistically related to long-term average climatic conditions. Also, in the absence of monthly disease data for the validation areas, the posterior probability that long-term temperature and rainfall variable thresholds were met was useful for relating sketchy published disease information to the climatic thresholds.

New modeling approaches are required to make use of subjective information where quantitative disease data are lacking so that relationships between disease and the occurrence of two or more climatic variables simultaneously can be determined. Comparison between the approach used in this study and climatematching approaches (37) is also required. The possible use of the climatic thresholds derived in this study for forecasting European canker infection risk from year to year in areas where the disease is a recurring problem merits further study. The potential impacts of changes in climate on disease distribution could also be facilitated using the results of this study (19).

\section{APPENDIX}

The WAVE method for deriving hourly from daily temperature. Temperature $T_{H}$ for a given hour $H$ was estimated from daily maximum $T_{M A X}$ and minimum $T_{M I N}$ temperatures as described by Reicosky et al. (35):

$T_{H}=\left\{\begin{array}{lc}T_{A V G}-0.5 \cdot T_{A M P} * \cos \left[\pi \cdot\left(H-H_{R I S E}\right) /\left(H_{M A X}-H_{R I S E}\right)\right] & \left(H_{R I S E}<H \leq H_{M A X}\right) \\ T_{A V G N}+0.5 \cdot T_{A M P N} * \cos \left[\pi \cdot\left(H-H_{M A X}\right) /\left(10+H_{\text {RISE }}\right)\right] & \left(H \leq H_{R I S E} \text { or } H>H_{M A X}\right)\end{array}\right.$

where $H_{R I S E}=$ the time of sunrise, $H_{M A X}=$ the hour at which maximum temperature occurred in a day. The values of $H_{\text {RISE }}$ and $H_{M A X}$ varied by month (Table 6). $T_{A V G}$ and $T_{A M P}$ were the average and range of temperature in a day, respectively, and were calculated as follows:

$$
T_{A V G}=\left(T_{M A X}+T_{M I N}\right) / 2
$$

and

$$
T_{A M P}=\left(T_{M A X}-T_{M I N}\right) / 2
$$

$T_{A V G N}$ and $T_{A M P N}$, which were the average and diurnal range of temperature for a 24-h period from $H_{M A X}$, respectively, were calculated using equations $\mathrm{A} 2$ and $\mathrm{A} 3$, respectively, with $T_{M I N}$ in the next day. $T_{H}$ values were estimated from $H_{\text {RISE }}$ every minute.

Accuracy of the WAVE method was assessed by comparing daily and hourly temperature data at Geneva, NY. Hourly weather data were obtained from a member station of the Natural Resources Conservation Service's Soil Climate Analysis Network (http://www.wcc.nrcs.usda.gov/scan/). At that station $\left(42^{\circ} 53^{\prime} \mathrm{N}\right.$, $77^{\circ} 2^{\prime} \mathrm{W}$ ), which was adjacent to the Cooperative Observer Program station $\left(42^{\circ} 53^{\prime} \mathrm{N}, 77^{\circ} 2^{\prime} \mathrm{W}\right)$ for the daily data, hourly temperature data were obtained for 3,178 days from 1998 to 2006. For the monthly averages of hours at 11 to $16^{\circ} \mathrm{C}$ in a given year, the $R^{2}$ value between estimates and measurements was 0.96

TABLE 6 . Time of sunrise $\left(H_{R I S E}\right)$ and daily maximum temperature $\left(H_{M A X}\right)$ obtained from Chow and Levermore (6)

\begin{tabular}{llcc}
\hline Month in $\mathrm{NH}^{\mathrm{a}}$ & Month in $\mathrm{SH}^{\mathrm{b}}$ & $H_{\text {RISE }}$ & $H_{\text {MAX }}\left({ }^{\circ} \mathrm{C}\right)$ \\
\hline January & July & 6 & 14 \\
February & August & 6 & 14 \\
March & September & 5 & 14 \\
April & October & 5 & 15 \\
May & November & 4 & 15 \\
June & December & 4 & 16 \\
July & January & 4 & 15 \\
August & February & 5 & 15 \\
September & March & 5 & 15 \\
October & April & 6 & 14 \\
November & May & 6 & 14 \\
December & June & 7 & 14 \\
\hline
\end{tabular}

${ }^{a} \mathrm{NH}$ and $\mathrm{SH}$ indicate northern and southern hemispheres, respectively. 
and the slope of the linear regression line was 1.09. The possibility of improving the accuracy of the WAVE method by calculating values of $H_{R I S E}$ and $H_{M A X}$ each day using an algorithm for solar position prediction $(5,29)$ was investigated. When estimates of hours at 11 to $16^{\circ} \mathrm{C}$ were calculated for eight sites using a solar position algorithm, the results were very similar $\left(R^{2}=0.98\right)$ to those using the tabulated monthly values of $H_{R I S E}$ and $H_{M A X}$.

\section{ACKNOWLEDGMENTS}

This work was supported in part by New Zealand's Foundation for Research, Science and Technology (Contract C06X0709). We thank East Malling Research, UK for provision of meteorological data and J. Palmer and R. Scheper for helpful comments on the manuscript draft.

\section{LITERATURE CITED}

1. Atkinson, J. D. 1971. Pages 70-74 in: Diseases of Tree Fruits in New Zealand. Government Printer, Wellington, New Zealand.

2. Berrie, A. M. 1989. Storage rots of apple and pear in South-East England 1980-88: incidence and fungicide resistance. Pages 229-239 in: IOBC Bull. 1989/XII/6, Vol. II, Integrated Control of Pome Fruit Diseases. B. K. Gessler, ed. IOBC, Locarno, Switzerland.

3. Bloksma, J., Jansonius, P. J., Heijne, B., and Anbergen, R. H. N. 2000. Calcium hydroxide against apple canker (Nectria galligena). Pages 30-32 in: 9. Internationaler Erfahrungsaustausch über Forschungsergebnisse zum Ökologischen Obstbau. Beiträge zur Tagung vom 3.-4. M. Boos, ed. Weinsberg, Germany.

4. Bulit, J. 1957. Contribution a l'etude biologique du Nectria galligena Bres. Agent du chancre du Pommier. Ann. Epiphyt. Sér. C. 1:67-89.

5. Cesaraccio, C., Spano, D., Duce, P., and Snyder, R. L. 2001. An improved model for determining degree-day values from daily temperature data. Int. J. Biometeorol. 45:161-169.

6. Chow, D. H. C., and Levermore, G. J. 2007. New algorithm for generating hourly temperature values using daily maximum, minimum and average values from climate models. Build. Serv. Eng. Res. Technol. 28:237-248.

7. Coakley, S. M., McDaniel, L. R., and Shaner, G. 1985. Model for predicting severity of Septoria tritici blotch on winter wheat. Phytopathology 75:1245-1251.

8. Cooke, L. R. 1999. The influence of fungicide sprays on infection of apple cv. Bramley's seedling by Nectria galligena. Eur. J. Plant Pathol. 105:783-790.

9. CPCI. 2009. Crop Protection Compendium on Internet. CAB International, Wallingford, UK.

10. Crowdy, S. H. 1952. Observations on apple canker (Nectria galligena). IV. The infection of leaf-scars. Ann. Appl. Biol. 39:569-587.

11. Dietterich, T. G. 2000. An experimental comparison of three methods for constructing ensembles of decision trees: Bagging, boosting, and randomization. Mach. Learn. 40:139-157.

12. Dubin, H. J., and English, H. 1974. Factors affecting apple leaf scar infection by Nectria galligena conidia. Phytopathology 64:1201-1203.

13. Dubin, H. J., and English, H. 1975. Epidemiology of European apple canker in California. Phytopathology 65:542-550.

14. English, H., Dubin, H. J., and Schick, F. J. 1979. Chemical control of European canker of apple. Plant Dis. Rep. 63:998-1002.

15. Goslee, S. C., Peters, D. P. C., and Beck, G. 2006. Spatial prediction of invasion success across heterogeneous landscapes using an individualbased model. Biol. Invasions 8:193-200.

16. Grove, G. G. 1990. Nectria canker. Pages 35-36. in: Compendium of Apple and Pear Diseases. A. L. Jones and H. S. Aldwinckle, eds. American Phytopathological Society, St. Paul, MN.

17. Hijmans, R. J., Cameron, S. E., Parra, J. L., Jones, P. G., and Jarvis, A. 2005. Very high resolution interpolated climate surfaces for global land areas. Int. J. Climatol. 25:1965-1978.

18. Houston, D. R. 1994. Temporal and spatial shift within the Nectria pathogen complex associated with beech bark disease of Fagus grandifolia. Can. J. For. Res. 24:960-968.

19. Huntley, B., Green, R. E., Collingham, Y. C., Hill, J. K., Willis, S. G., Bartlein, P. J., Cramer, W., Hagemeijer, W. J. M., and Thomas, C. J. 2004. The performance of models relating species geographical distributions to climate is independent of trophic level. Ecol. Lett. 7:417-426

20. Jansonius, P. J., Zanen, M., and Bloksma, J. 2004. Annual Report 2003 LBI Organic Fruit Growing Research: Including plans for 2004. Louis Bolk Instituut Publications, LF78.

21. Kari, J. S., and Huey, R. B. 2000. Size and seasonal temperature in freeranging Drosophila subobscura. J. Therm. Biol. 25:267-272.
22. Kriss, A. B., Paul, P. A, and Madden L. V. 2010. Relationship between yearly fluctuations in Fusarium head blight intensity and environmental variables: A window-pane analysis. Phytopathology 100:784-797.

23. Kühn, B. F. 2004. Susceptibility to apple scab, Nectria cancer and powdery mildew of different unsprayed apple varieties. Pages 221-226 in: Proc. XIth Int. Conf. Cultivation Technique and Phytopathological Problems in Organic Fruit-Growing and Viticulture. M. Boos, ed. Weinsberg, Germany.

24. Latorre, B. A., Rioja, M. E., Lillo, C., and Muñoz, M. 2002. The effect of temperature and wetness duration on infection and a warning system for European canker (Nectria galligena) of apple in Chile. Crop Prot. 21:285291.

25. Lolas, M., and Latorre, B. A. 1996. Importancia y control del cancro europeo del manzano. Rev. Frut. 17:23-27.

26. McCartney, W. O. 1967. An unusual occurrence of eye rot of apple in California due to Nectria galligena. Plant Dis. Rep. 51:278-281.

27. McCracken, A. R., Berrie, A. M., Barbara, D. J., Locke, T., Cooke, L. W., Phelps, K., Swinburne, T. R., Brown, A. E., Ellerker, B., and Langrell, S. R. H. 2003. Relative significance of nursery infections and orchard inoculum in the development and spread of apple canker (Nectria galligena) in young orchards. Plant Pathol. 52:553-566.

28. McNemar, Q. 1947. Note on the sampling error of the difference between correlated proportions or percentages. Psychometrika 12:153-157.

29. Meeus, J., 1991. Astronomical Algorithms. Willmann-Bell, Richmond, VA.

30. Nepstad, D., Carvalho, G., Barros, A. C., Alencar, A., Capobianco, J. P., Bishop J., Moutinho, P., Lefebvre, P., Silva, U. L., and Prins, E. 2001. Road paving, fire regime feedbacks, and the future of Amazon forests. For. Ecol. Manage. 154:395-407.

31. Nichols, C. W., and Wilson, E. E. 1956. An outbreak of European canker in California. Plant Dis. Rep. 40:952-953.

32. Ogawa, J. M., and English, H. 1991. Diseases of Temperature Zone Tree Fruit and Nut Crops. Publication 3345, University of California, Division of Agriculture and Natural Resources, Oakland, CA..

33. Pedersen, H. L. 2007. Effect of rapid or slow release nitrogen supply and cover crop/weed management on crop yield, pest incidence and fruit quality in intensive organic apple production. Pages 296-300 in: Improving Sustainability in Organic and Low Input Food Production Systems. In: Proc. 3rd Int. Congr. Eur. Integrated Project Quality Low Input Food (QLIF). U. Niggli, C. Leifert, T. Alföldi, L. Lück, and H. Willer, eds. University of Hohenheim, Research Institute of Organic Agriculture FiBL, CH-Frick, Germany.

34. Ransom, L. M. 1997. The eradication of Nectria galligena from apple trees in Tasmania, 1954-1991. Australas. Plant Pathol. 26:121-125.

35. Reicosky, D. C., Winkelman, L. J., Baker, J. M., and Baker, D. G. 1989. Accuracy of hourly air temperatures calculated from daily minima and maxima. Agric. For. Meteorol. 46:193-209.

36. Sadler, E. J., and Schroll, R. E. 1997. An empirical model of diurnal temperature patterns. Agron. J. 89:542-548.

37. Sutherst, R. W., and Maywald, G. F. 1985. A computerised system for matching climates in ecology. Agric. Ecosyst. Environ. 13:281-299.

38. Swinburne, T. R. 1971. The seasonal release of spores of Nectria galligena from apple cankers in Northern Ireland. Ann. Appl. Biol. 69:97-104.

39. Swinburne, T. R. 1975. European canker of apple (Nectria galligena). Rev. Plant Pathol. 54:787-799.

40. Teng, P. S., and Yang, X. B. 1993. Biological impact and risk assessment in plant pathology. Annu. Rev. Phytopathol. 31:495-521.

41. Weltzien, H. C. 1972. Geophytopathology. Annu. Rev. Phytopathol. 10:277-298.

42. Wessel, H. 1980. Untersuchungen zum einfluss von klimafaktoren auf die entwicklung des krebses (Nectria galligena) an apfel. Med. Fac. Landbouwwet. Rijksuniv. Gent. 45:183-190.

43. Wilson, E. E. 1966. Development of European canker in a California apple district. Plant Dis. Rep. 50:182-186.

44. Wiltshire, S. P. 1921. Studies on the apple canker fungus. I. Leaf scar infection. Ann. Appl. Biol. 8:182-192.

45. Xu, X.-M., and Butt, D. J. 1994. The biology and epidemiology of Nectria galligena and an infection warning system. Norw. J. Agric. Sci. Suppl. No. 17:317-324.

46. Xu, X.-M., and Butt, D. J. 1996. Tests of fungicides for post-germination activity against Nectria galligena, causal agent of canker and fruit rot of apple. Crop Prot. 15:513-519.

47. Xu, X.-M., Butt, D. J., and Ridout, M. S. 1998. The effects of inoculum dose, duration of wet period, temperature and wound age on infection by Nectria galligena of pruning wounds on apple. Eur. J. Plant Pathol. 104:511-519.

48. Xu, X.-M., and Robinson, J. D. 2010 Effects of fruit maturity and wetness on the infection of apple fruit by Neonectria galligena. Plant Pathol. 59:542-547.

49. Zeller, S. M. 1926. European canker of pomaceous fruit trees. Oreg. Agric. Exp. Stn. Bull. 222. 